Pace University

DigitalCommons@Pace

$1-1-1999$

\title{
The National Association of Honest Lawyers: An Essay on Honesty, "Lawyer Honesty" and Public Trust in the Legal System
}

John A. Humbach

Elisabeth Haub School of Law at Pace University

Follow this and additional works at: https://digitalcommons.pace.edu/lawfaculty

Part of the Legal Ethics and Professional Responsibility Commons

\section{Recommended Citation}

John A. Humbach, The National Association of Honest Lawyers: An Essay on Honesty, "Lawyer Honesty' and Public Trust in the Legal System, 20 Pace L. Rev. 93 (1999), http://digitalcommons.pace.edu/ lawfaculty/90/.

This Article is brought to you for free and open access by the School of Law at DigitalCommons@Pace. It has been accepted for inclusion in Pace Law Faculty Publications by an authorized administrator of DigitalCommons@Pace. For more information, please contact dheller2@law.pace.edu. 


\title{
Article
}

\section{The National Association of Honest Lawyers: An Essay on Honesty, "Lawyer Honesty" and Public Trust in the Legal System}

\author{
John A. Humbach*
}

The growing public disquiet about lawyer ethics is not mainly because people think lawyers neglect their professional standards. Rather, the main problem is the belief among lawyers that the duty of loyalty to clients requires a lawyer to mislead. Specifically, the ethical duty of confidentiality and the ethical duty of zealous advocacy are interpreted together to mean that lawyers must conceal some facts ("confidentiality") while forcefully asserting others. This mis-coupling of these two key ethical duties has an inevitable tendency to produce a kind of partial-truth advocacy in which the lawyer knowingly distracts attention from the truth and fosters misconceptions in the minds of jurors and others. In the end, lawyers frequently succeed in creating false impressions or discrediting the truth and, as a result, people feel they cannot trust lawyers to be straight.

Distrust of lawyers is not, however, just an image problem of an insular profession. Our basic civic order relies on the legal system and public respect for it. If the public cannot trust the lawyers who are entrusted with the legal system, there is a problem that casts a shadow on the integrity of the very concept of rule of law.

This essay addresses these issues and proposes one possible solution. Its objective is to provide a basis for thinking about how, con-

* J.D. summa cum laude, Ohio State University (1966). Professor of Law, Pace University School of Law, White Plains, New York. My gratitude is expressed to Peter C. Kostant and Steven H. Goldberg without whose encouragement and helpful suggestions this essay would not have been written. 
cretely, we can move from the present stage of lawyer ethics to a more advanced stage in which the legal profession will become a truly forthright and credible social institution.

I.

Lawyers can either be trusted or they cannot. The regrettable fact is that lawyers, on the whole, can not be trusted. The reason is not merely that some lawyers sometimes do not tell the truth. The problem is far more systematic and pervasive. The reason lawyers cannot be trusted is that, on the questions that ultimately matter, most lawyers do not even purport to present the objective truth.

A lawyer may not tell direct lies, ${ }^{1}$ nor help the client to lie, ${ }^{2}$ but the lawyer has a far more subtle art. The lawyer's skill is to weave stories that are false out of statements that are true. They do this in part by purposely withholding pertinent information knowing full well of the misunderstandings they promote in doing so. ${ }^{3}$ They deliberately undermine the credibility of truthful information and evidence that may be damaging to their clients. ${ }^{4}$ They make great efforts to encourage jurors and others to form misleading impressions of their clients and of past events. ${ }^{5}$ And in a variety of other contexts, the versions of reality that lawyers attempt to portray do not even purport to correspond to the actual facts as either the lawyer or the client honestly sees them.

On the contrary, most lawyers will probably agree that, in their pursuit of values other than truth, they have not merely the right but even the duty to mislead. If a business client does

1. See Model Rules of Professional Conduct Rule 4.1(a) (1983) (hereinafter "MOdEL Rules").

2. See Model Rules Rule 1.2(d) (1983).

3. See Model Rules Rule 1.6(a) and cmt. 9 (1983). See also Spaulding v. Zimmerman, 116 N.W.2d 704, 710 (Minn. 1962) (suggesting that there is not even a duty to notify another party of a deadly peril that may kill him at any moment).

4. See, e.g., Monroe Freedman, Cross Examination: Destroying the Truthful Witness, in Lawyer's Ethics in an Adversary System 43-49 (1975); Jerome Frank, Courts on Trial 82-83 (1963), quoted in United States v. Wade, 388 U.S. 218, 256 (1966) (White, J., dissenting).

5. See United States v. Wade, 388 U.S. at 257-58; see generally Francis H. Hare, Jr., et al., Full Disclosure: Combating Stonewalling and Other DisCOVERY ABUSES (1994). 
not want to reveal the whole story in negotiating a deal, it is not the lawyer's job to disturb the false impressions the other side forms as a result. 6 If a guilty client wants to say "I didn't do it," then that client's innocence is the picture of reality the lawyer is expected to convey. ${ }^{7}$ Even if the client offers the lawyer no remotely plausible denial of guilt, lawyers see their duty as clear: to try to raise "reasonable doubt" by pressing the jury to accept, at least provisionally, notions about reality that neither the lawyer nor the client takes to be true. ${ }^{8}$ Even the venerable American Bar Association (hereinafter ABA) publishes suggestions that the lawyer's "best bet to win a bad case may well be to confuse the judge or jury," creating a "need to obfuscate." There is no way around it. Lawyers claim a professional duty to deceive.

When talking among themselves, most lawyers make no bones about their position on truth. Though most lawyers really do try to avoid telling outright lies, most also regard it as a central part of their task to bend perceptions of the facts to their client's advantage. Lawyers do not consider such "fact management" to be grounds for reproach. On the contrary, skills in this area are widely regarded as key elements in the effective advocate's repertory. ${ }^{10}$ Law schools that overly stress the learning of legal "doctrine" instead of such "skills" are obliquely criticized by commissions of the organized bar. ${ }^{11}$ Many a time I have

6. See supra note 3 .

7. See Model Rules Rule 3.1 (1983). See also Michigan Opinion CI-1164 (1987), reprinted in RichaRD A. Zitrin \& CAROL M. LangFord, Legal Ethics IN the Practice of Law 253-54 (1995); and Restatement of the Law Governing LAWYERS $\S 170(2)$ and cmt. f and Reporter's Note to cmt. f (1983) (Tentative Draft No. 8,1997$)$.

8. See James B. Mitchell, Reasonable Doubts Are Where You Find Them: A Response to Professor Subin's Position on the Criminal Lawyer's 'Different Mission," 1 GEo. J. LEGAL ETHICS 339, 343-46 (1987) (discussing the "pure reasonable doubt" defense).

9. Frederic G. Gale \& Joseph M. Moxley, How to Write the Winning Brief: Strategies for Effective Memoranda, Briefs, Client Letters, and Other Legal Documents 132 (1992).

10. See, e.g., Robert MacCrate, Legal Education and Professional Development - An Educational Continuum 1992 A.B.A. Sec. of Legal Education and AdmisSIONS TO THE BAR 138-39 (strongly urging increased law school attention to such non-doctrinal skills as "factual investigation," "communication," "negotiation," and client "counseling").

11. See id. at 3-7, 124-25; Professional Education Project, Legal Education and Professional Development in New York State 24 (1996). 
heard lawyers deride the idea of requiring full and candid disclosures as impractical and naive, not to mention contrary to the clients' wishes. Some even deny that there is such a thing as knowable, objective truth. ${ }^{12}$ Past events are what we make them.

In partial defense, it should be said that many lawyers sincerely believe, with good reason, that their clients generally want things just the way they are. Even if a client does not seek an unfair edge by means of outright falsehood, most clients would probably not want to lose an advantage just because their lawyer blurts out a weakness in their case. Still, the profession must bear at least partial responsibility for cultivating the client's expectations in this regard. Most citizens probably think that their actions are, for better or worse, to be judged by the substance of the law. It is above all the lawyer who counsels the decadent hope that, whatever you have done, "maybe they can't prove it." Whatever you have to hide in negotiations, "maybe they won't find out." The loopholes and escapes of procedure and evidence are the lawyer's stock in trade.

The problem of lawyer honesty with respect to facts is not, however, a mere tangential annoyance. When lawyers counsel concealment instead of pursuing truth, they are deliberately contriving to lead the law astray-causing its rules to misapply by distorting the factual base. The effect is to undermine the sovereignty of doctrine and detach legal holdings of "right" and "wrong" from the intent of the substantive law. The public correctly perceives a disconnect at the crucial juncture that controls the impact of government on people's lives. The system's premises of "government by law" are derailed by the lawyerswayed outcomes that people actually get.

Nevertheless, a lawyer who conceals the truth in the name of protecting client secrets is not violating the lawyer's code of ethics. The American Bar Association has made sure of that. ${ }^{13}$ Seventeen years ago, an ABA commission to revise the ethical

12. See, e.g., Steven H. Goldberg, Heaven Help the Lawyer for a Civil Liar, 2 Geo. J. Legal Ethics 885, 912-16 (1989). Cf. Geoffrey C. Hazard, JR., Ethics in THE PRACTICE OF LAW 122 (1978) and Quis custodiet ipsos custodes? 95 YALE L.J. 1523, 1529 (1986). See also Mitchell, supra note 8, at 349 n.29; Harry I. Subin, The Criminal Lawyer's "Different Mission": Reflections on the "Right" to Present a False Case, 1 Geo. J. Legal Ethics 125 (1987) (criticizing the view).

13. See Model Rules Rule 1.6(a) (1983). 
canons tried to reform the "confidentiality" rule. ${ }^{14}$ Under the commission's proposal, lawyers would be permitted to reveal their client's intentions to defraud. ${ }^{15}$ The proposal was never accepted and, later, an even more modest proposal was rejected. ${ }^{16}$ Under the rules as they exist today, lawyers are only allowed to inform on their clients when the client's plans threaten to cause imminent death or substantial bodily harm. ${ }^{17}$ An abuser who tells his lawyer that he intends to beat his wife, but only moderately, can rest in the assurance that his lawyer's ethical standards will keep the secret safe.

Most lawyers receive their first exposure to the intricacies of such legal "ethics" in law school. I remember my own law school days when the subject was tolerantly received as part of a required course in clinical law practice. For me, however, the lesson in legal ethics that really made an impression came later, shortly after I entered practice in the corporate department of a (then) Wall Street law firm. Sitting one evening in a senior associate's office, I was asked: "Do you know why the firm can charge the high fees it does?" I wondered what he was going to say. "Because," he said, "when we telephone the government examiner and say the documents are on the way, or that thus-and-so is true, he can take us at our word. Our client's deal moves right ahead without expensive delays. Not every law firm can do that." There was a pause. "You don't want to be the one to mess that up."

14. See Selected Statutes, Rules and Standards on the Legal Profession 21 note * (John S. Dzienkowski ed., 1994). The commission was known as the Kutak Commission. See also American Bar Association, Annotated Model Rules of Professional Conduct 70 (1984).

15. Specifically, the proposed change would have allowed lawyers to disclose information in order to prevent fraudulent acts that the lawyer believed likely to result in substantial financial or property injury to another. See Selected Statutes, Rules and Standards on the Legal Profession 21 note * (John S. Dzienkowski ed., 1994).

16. In 1991, the ABA House of Delegates rejected a proposal to let lawyers disclose confidences in order to rectify the consequences of client frauds that had been perpetrated with the help of the lawyer's services. See id. See also Stephan Gillers \& Roy D. Simon, Regulation of Lawyers: Statutes and Standards 7375 (1999). A number of states have declined to follow the ABA lead and some have relaxed the rules of confidentiality, though not much. See id.

17. See Model Rules Rule 1.6(b)(1) (1983). The only other exception to confidentiality is for when the lawyer is litigating against his or her own client. See also Model Rules Rule 1.6(b)(2) (1983). 
The message was simple. Being known as an honest lawyer has real advantages, measurable in dollars and cents. Of course, honesty for its own sake-for the pure moral rectitude of it all-is a fine ambition too. But being honest for the self-serving good for all concerned is not such a different thing. Either way, coldly practical or earnestly goody-goody, the point is the same: Being an honest lawyer pays off.

More recently, in a similar vein, I heard of the lament of a young lawyer who had the tough job of representing people involuntarily committed for mental instability. All it takes in New York is two "physicians' certificates" and you can be "2PC'd" straight to a mental ward for 60 days. ${ }^{18}$ The young lawyer in question goes to court on behalf of these unfortunates, to the routine hearings that are held to decide if the 60-day confinement ought to apply. Most of the time, she privately concedes, the confinement is warranted. Even so, it is her job to make the best case she can for her client's release, and this she does, generally in vain. Her problem is this: In the comparatively few cases when confinement is not warranted, her legal argumentation usually ends up being just as futile as it is in all the others. By constantly urging the court to reach counterfactual conclusions, she has lost the credibility to do what she is fundamentally there to do. She has no effective ability to say to the judge: "Your Honor, this is a real one. This time I have a client who really should go home."19

II.

Despite the obvious advantages of embracing an unstinting commitment to the truth, the legal profession has serious problems when it comes to comprehensive honesty, faithfulness to reality and reputation for fair play. In dealing with the evidence or facts at their disposal, most lawyers see it as an advantage to play the game of hide the pea, at least some of the time. Of course it always goes by other names, such as "zealous representation"20 or duty of "confidentiality." 21 But whatever the

18. See N.Y. Mental Hygiene Law $§ 9.27$ (McKinney 1996).

19. $C f$. discussion infra note 37 and accompanying text.

20. $C f$. Model Code of Professional Responsibility Canon 7 (“A lawyer should represent a client zealously within the bounds of the law"); $c f$. MoDEL Rules Rule 1.3 cmt. 1 (1983). 
name, most lawyers would agree that it is wrong to disclose information that might weaken the client's position. Negotiating gamesmanship and playing close to the vest, while trying to figure out the other side's secrets, are fairly widely seen as very near the essence of good lawyering technique. Most probably feel that they would quickly lose their clients, and never manage to attract new ones, if they started making it a practice to reveal their own sides' secrets.

In a certain sense, to be sure, lawyers as a profession do maintain a commitment to truth. The ABA's Model Rules, for example, expressly prohibit any "false statement of material fact or law to a third person." 22 Moreover, it is probably fair to say that most lawyers do not believe that, due to their efforts, the law ends up applying to people's lives mostly on the basis of pseudo-facts. Despite their great respect for the power of advocacy, most would agree that the determinative facts of a case are more than simply a matter of comparative advocacy skill. Yet, few would deny that skillful advocacy plays a role, often a decisive one, in factual determinations. And few would deny that the larger pictures of "fact" that lawyers suggest for the consumption of others often do not correspond to the actual understanding of either the lawyer or the client. ${ }^{23}$

There are, however, exceptions. The practice of patent law is one of these exceptions. A lawyer in patent practice is expected to make a full and complete disclosure to the Patent Office, including all known reasons as to why an applied-for patent should not be granted. ${ }^{24}$ While the client is also expected to observe these duties of full disclosure, the compliance burden falls, in effect, on the practitioners themselves. It is a defense to an infringement action that the applicant or his attorneys did not comply with these rules of candor. In a similar vein, the clients of securities practitioners are routinely subject to requirements of full and fair disclosure in securities offering documents and other submissions to agencies. ${ }^{25}$ Again, the

21. Model Rules Rule 1.6 (1983).

22. Model Rules Rule 4.1(a) (1983).

23. The so-called "pure reasonable-doubt defense" in criminal cases is, perhaps, the unexcelled example of this kind of truth divergence. See Mitchell, supra note 8 , at 343-36.

24. See 37 C.F.R. $\S 1.56$ (1996).

25. See, e.g., 15 U.S.C.A. § 77k(a) (1981); 17 C.F.R. § 240.10b-5 (1996). 
compliance burden falls, in effect, on the lawyer. The catastrophic liabilities that can theoretically result from material non-disclosures have led to a rather strong ethic of due diligence in fact ascertainment and disclosure in this area of practice, too.

This is not to say that there are not occasional problems. Patent practitioners can be heard to complain that the Patent Office is less diligent than it should be in cracking down on colleagues who do not adequately police the fullness of their client's disclosures. From time to time there are reports of egregious lapses in a securities law firm's uncovering and revealing of negative facts about a securities issuer that it represents. Still, compared with the legal profession as a whole, these areas of practice are practically paradises of lawyer honesty.

The question occurs, why cannot the high standards of honest practice applied to patent attorneys and assumed by securities attorneys apply across the profession? How can it be made to happen?

\section{III.}

A National Association of Honest Lawyers would be a mechanism for providing a transition from our present stage of lawyer ethics to a more advanced stage in which the legal profession will become a truly forthright and credible social institution. The association, NAHL, would exist for the purpose of establishing and certifying its members' compliance with a set of ethical practice standards that go well beyond the tepid and inconsistent requirements of candor in the present ethical codes. Membership in NAHL would be voluntary. It would be open to all practitioners who agree to adhere to NAHL's ethical standards and to accept its monitoring of their compliance. NAHL members would be entitled to hold themselves out as such.

Under the NAHL standards, member lawyers would undertake to provide, without being asked, a full and fair disclosure of all material facts and evidence that come into their possession-to the courts, to juries and to all those with whom they and their clients deal. Members would also be expected to use due diligence to assure that their clients are equally forthcom- 
ing in the matters in which the member represents them. Clients desiring to retain NAHL members would be required to waive claims of confidentiality (including the lawyer-client privilege) in their retainer agreements. They would be required to agree that, in the course of representation, the lawyer would in no instance seek any legal or tactical advantage by fabricating controversy or pretending disagreement with respect to any matter of past or present fact. NAHL members would try never to present positions or induce understandings that they or their clients know to be false or misleading, nor to assert factual positions as to which their client is in material doubt without also disclosing the basis for that doubt.

In many situations, of course, an attorney will be at such a distance from the actual event that it will be hard, as a practical matter, for the attorney to form a very strong belief one way or the other as to factual matters in actual or potential controversy. The attorney is not, however, at a distance from the client. The important thing is for the lawyer to believe that the client actually believes the version of the facts that the lawyer presents on the client's behalf. That is, a position or understanding as to a matter in potential controversy is not considered to be false or misleading if the lawyer honestly believes, after due diligence, that the client honestly believes it to be true. To present the client's honestly held views and values is not deception because everyone knows that presenting the client's version of things is precisely the lawyer's job. The lawyer does not "vouch for" the client, but the lawyer does vouch for his or her own diligence in determining the understanding of reality that the client truly has.

Needless to say, the "client's honestly held views and values" do not refer to views and values that the attorney has implanted in the client's mind. Therefore, the NAHL lawyer would need to carefully avoid ever making a suggestion, direct or oblique, that the client would do well to adopt certain "honest beliefs" in order to obtain some legal or tactical advantage. On the contrary, as a key player in a process aimed at getting to truth, the honest lawyer's first task would be to endeavor diligently to get the client to provide as much as possible of the truth as the client sees it. 
Getting at the truth as the client sees it calls for interviewing and fact-gathering skills. The lawyer must, among other things, confront the client with inconsistencies (of which the client may well not even be aware), and with all of the lawyer's suspicions and reasons for doubt. It implies also the need to confront the client with inculpatory or other contrary evidence known to the lawyer, and to get the client to make his or her story cohere, both internally and with the external evidence. In this ongoing process, the lawyer's approach would be somewhat analogous to the kind of questioning that might be done in preparing a client for cross-examination-the posture is that of friend, not foe, but it is nevertheless deeply probing.

The idea is, in short, to make an honest and diligent effort to elicit, perhaps even "reconstruct" (but never to newly construct), the client's honestly held side of things, whether it relates to a prospective business negotiation, a criminal accusation, a civil controversy or other legal matter. It is to be based solely on this "honestly held side of things" that the honest lawyer would diagnose and counsel concerning the client's legal situation and, if litigation or negotiations ensue, make the client's case.

Sometimes, to be sure, there is no amount of due diligence that can resolve the lawyer's doubts. When confronted with inculpatory or other contrary evidence an accused may say: "I just can't explain that, but I really didn't do it," or "that guy is just plain wrong." In such cases, and others, the lawyer simply will not know, despite the best of efforts, whether the client is telling the truth. When situations like these arise, the presumption can fairly favor the client, and the lawyer would then present the client's resolutely held version of things, admitting the contrary information and evidence, as best the lawyer can. After all, honesty and diligence only mean doing all you can never to mislead; they do not mean omniscience. The key is that before going public the honest lawyer should have it out with the client as to any and all discrepancies. He or she must be satisfied that the version of reality being presented is one that is, to the greatest extent possible, fundamentally coherent with other information known to the lawyer and, most importantly, the one that the client truthfully holds. 
Finally, there will always be some situations in which the client will not be able to have any coherent beliefs at all on the subject at hand, such as when the client is of tender years, mentally incompetent or simply in the dark. In some roles, such as prosecutor, lawyers may not have a "real" breathing client at all. In such situations, the only thing the honest lawyer could do is to portray the truth as the lawyer sees it, along with any material doubts that he or she might have as to the accuracy of that portrayal. The honest lawyer would not, however, be free in this (or any other) situation to argue for a version of "reality" just because it happens to be one that is legally beneficial for the client.

\section{IV.}

NAHL's primary role would be to serve as an independent external certifying body and, as such, it would investigate and report on grievance complaints alleging dishonesty by its members. Its primary "sanction" would be to keep a readily available public record of these reports (for example, on the Internet) and to revise its certifications on the basis of them.

If a charge is made that a member lawyer has acted in a misleading way, whether in presenting a client's story, pretending a controversy or otherwise, NAHL would investigate. In such investigations, it will be up to the member lawyer to provide evidence of his or her due diligence in ascertaining what the client actually believed and of the lawyer's efforts with the client to bring out an internally coherent version of events. Good record keeping, including audio-visual records, would greatly expedite such inquiries. Most unfounded grievance complaints could probably be dealt with by a simple interview which, as in all else, the member would approach with the utmost candor.

Suffice it to say that NAHL's oversight would bear no relation to the cumbersome and lengthy grievance procedures that characterize the current system of self-regulation of the bar. The basic NAHL standard, a simple and straightforward rule of full and complete disclosure, should be easier to enforce precisely because it would not include the arcane compromises and over-refined distinctions that mark the existing ethical rules. There should be few questions about conduct "close to the line" 
because allowing oneself to come close to the line-allowing people to form questionable impressions without disabusing them-would itself be less than ingenuous and, hence, over the line. People generally know when they have been had, and the central focus of NAHL members' dealings with others would be to pursue their clients' legally justified interests while endeavoring diligently never to leave others with the sense of being had. This is not such a complicated thing to do if one is alert, forthright and genuinely tries. Nor is it such a difficult thing to determine, after the fact, if someone really has been taken in because a lawyer skipped a chance to head off a foreseeable blunder, ambush or surprise.

Nevertheless, enforcement could not be the core of NAHL's effectiveness. NAHL's limited resources would quickly be overcome (and its objectives utterly thwarted) if it had to rely very extensively on investigation and sanctions in order to bring about honest practice among members of the bar. NAHL will have to depend, as most normative systems, on peer reinforcement and eventual general acceptance of the view that its honest practice precepts are right.

Such a general acceptance would, however, be no small thing. People tend to do what they think is right and to avoid what they see as wrong. Surely it would be a powerful step for a body of lawyers to formally acknowledge, by declaration and by actual practice, that currently common techniques of deception, concealment and dissimulation are simply unacceptable-much as outright lying and fraud are regarded now. A NAHL lawyer who is discovered trying to get a client something extra by withholding information or pretending controversy would not receive the grudging toleration or even admiration that sharp lawyers may enjoy today. No NAHL lawyer would want a reputation for such practices. The main goal of NAHL would be, in short, to extend the cloud of disapprobation to the now-permitted forms of deception practiced by the bar.

Skeptics are certain to point out that NAHL's ethical preachments and the possible fear of outraging others will still leave many lawyers with irresistible temptations to advance their clients' interests in deceptive ways. While this may be true, the same may be said of the current rules against outright lying, suborning perjury, manufacturing evidence and the like. 
They certainly do not totally prevent such conduct, but no one suggests that is a reason to give them up. On the contrary, the existing bans are surely effective in at least dampening the resort to the forbidden techniques. The higher ethical standards propounded and backed up by NAHL should be likewise effective in dampening the resort to techniques that presently discredit the profession.

Indeed, lest one underestimate the dampening effect of having standards in place, consider how different litigation would be if advocates applied only the honesty standards that are applicable to political campaigns. Like litigation, political campaigns are an "adversary system" at the heart of our governmental system, but unlike litigation they function with practically no honesty rules at all. While political campaigns and litigation both rely mostly on the ability of the adversaries to catch each other in falsehoods, it is hardly a mark of serious dishonor in politics to be caught in a palpable lie. In litigation, by contrast, to be caught in a lie can be deadly to the cause, a fact that makes litigation-even under today's relaxed standards-a far better tool than political campaigns for getting at the truth. As the higher standards of NAHL came to be the norm of "acceptable" lawyering behavior, litigation would be even less often sidetracked by camouflage and evasions and, therefore, all the more reliable as a truth finding process.

Why, it may be asked, would any lawyer voluntarily submit to the burden of NAHL supervision? The answer is that NAHL membership, and the certification it would carry, should provide constant advantages, both to the member and to his or her clients. Prime among these advantages, especially initially, would be the ability to hold oneself out as having a monitored commitment to the ethical precepts of NAHL-and to point out (whenever true) that one's counterpart does not. When a factfinder's determination comes down, as it so frequently does, to the bedrock question of whom to believe, the one with the certified and monitored duty of utter candor has an obvious advantage. A lawyer who is not willing to accept NAHL limitations on what he or she can say is a lawyer who, for all one knows, might say almost anything. Other things being equal, whom would you believe? If you were a client (unless you had 
something terrible to hide), whom would you want to have standing up for the rightness of your cause? ${ }^{26}$

\section{V.}

Beyond the individual advantages to the clients of members, NAHL would provide an even more important long-term advantage to society as a whole. Over time, it may be expected, the presence of certified honest lawyers would tend to drive out of practice those who are not willing to commit to full candor. The more profound consequence of NAHL, in other words, would be to reintroduce basic integrity into the nation's legal system.

When lawyers fiddle with the facts to dodge the brunt of the law, it is more than just a clever private victory. It is a major impediment to the proper functioning of the law itself. If the law's substantive rules provide for "justice," then any dissimilation or bending of facts to avoid those rules must tend to frustrate justice. If the substance of laws reflects the results of our democratic process, then lawyers' factual concealments and distortions cut to the heart of the democratic form of government itself.

Fundamentally, the legal system is founded on a set of substantive rules that serve as the standards for judging right and wrong in the ways we treat each other. These rules and the principles and policies they promote are the embodiment of justice, insofar as human institutions can succeed in reducing justice to law. To the extent that people's actions are judged according to these rules, the legal system functions according to its plan, and justice prevails according to the substance of the law. To the extent, however, that lawyers manage to undermine and conceal the evidence of what really happened, justice is subverted. No matter how fair and just its precepts, the sub-

26. Initially, of course, it is possible that in certain controlled settings, such as open court, honest lawyers might find that they are prohibited from calling attention to their membership in NAHL or to their adversary's lack of it. After all, those lawyers who are not willing to commit themselves to honest practice standards may have much to lose. They, along with their judicial supporters and sympathizers, may therefore want to move to prevent any advantages from accruing to fully honest ways of dealing with truth. Part of the task of NAHL will be to spotlight and challenge such concealments and to deprive the profession's non-honest traditions of the cloak they need to survive. 
stantive law can only apply to the facts that actually appear before it.

There is good reason to suspect that many cases are decided and many negotiations are settled differently than they would have been if the law's substantive rules had been applied to the actual facts of the situation. It is, indeed, frequently the conscious objective of lawyers to help their clients avoid a legal result that the law itself would call for-to make sure, for example, that whatever really happened, "they can't prove it." The result is a good deal of fabricated controversy in situations where there is no real difference between the parties' actual understandings of the facts or applicable legal policies. The attraction of pretending controversy in such cases stems from the possibility it offers to make a play on basic features of the process itself-the costs that it imposes on the opponent, the uncertainties it engenders, and the opportunity for lucky "accidents" that it provides. The hope is essentially to eke out better than one deserves.

Controversies pursued as a play on the process do not, however, serve any bona fide purpose, and there is no reason for them to be encouraged. They are parasitic to a vital social function, adding nothing to it and detracting substantially from it. Honest lawyers, by assuring themselves that they are pressing only the honestly held beliefs and values of their clients, would minimize the amount of fabricated controversy. The processes of law and negotiation could then be left to focus on those disputes that are founded on genuine divergences of viewpoint or understanding.

In sum, when lawyers succeed in hiding or distorting the real nature of a person's actions, the law's application will likewise be distorted, and the justice it embodies cannot prevail. The public realizes that these effects occur, and the poor reputation of lawyers is, at least in part, because the public does not generally care for the result. The substantive law may not be perfect in its justice, but it does reflect the results of our democratic process of government. Whatever the law's substantive imperfections, it is doubtful that it can be improved by stinting on the commitment to truth in finding the facts to which it applies. 
VI.

If the public does not appreciate the effects of lawyers' factual concealments and distortions, why have such concealments and distortions acquired such a prominent role in everyday law practice, and why is a special effort, perhaps a special organization, needed to eradicate them from respectability? The problem of incomplete lawyer honesty seems to stem from a combination of several systemic forces.

One of the systemic pressures against total candor in advocacy is that not everyone actually wants the results that the laws provide. The person who has committed a crime does not want to go to prison. The person who finds a contract burdensome does not want to pay damages in a suit for breach. The person who suffers a minor, transitory injury may not want to be limited to only a nominal recovery of damages. With a smart lawyer, one who is able to deal creatively with the facts, "undesired" legal results such as these can be avoided, even legally avoided, under the system as it stands.

Indeed, the cast that lawyers place on the facts of a matter is so critical to the outcome that many earnestly urge, as noted earlier, that the emphasis on learning "laws" in law school goes way too far. ${ }^{27}$ Students should, they say, devote more of their time to learning how to work the facts to the client's advantage. However, elevating the portrayal of the facts over the sovereignty of doctrine is ultimately an affront to the very concept of "rule of law." The lawyer's commitment should be to the facts themselves, as best we can honestly garner them. For it is only the facts themselves, appraised in terms of the law's substantive rules, that can legitimately define who is right and who is wrong in human affairs.

Another of the systemic pressures against total candor in advocacy comes from the recognition that, no matter what, some factual distortions are inevitable, and they probably always will be. No system created and run by human beings can ever be perfect, and this is perhaps especially so of a system of justice, with all the contending powers and forces that inevitably bear upon it. However, even if no system can give a perfect picture of actual "truth," that in no way supports the lawyer's

27. See supra text accompanying notes 10-11. 
pretense that a suitable ersatz for truth somehow emerges from our present-day process of competitive scenario building. The fact that perfection is unattainable does not mean that any sort of imperfection is equally fine.

No matter how carefully a marksman aims, he or she will sometimes miss the target. But that does not mean it does not matter whether the marksman aims at all. It is likewise for lawyers as the trustees of the legal process. No matter how hard they try they will sometimes miss the truth, but that hardly means that they should not embrace the highest standards of honesty, full disclosure and truth-seeking in everything they do.

Still another systemic pressure against total advocacy candor flows out of a deep attraction that many lawyers seem to have to a certain combative version of the adversary system. This particular version of the adversary system is founded on the premise that letting each side do its worst-short of outright lies-is the best method for getting at the truth. If the oarsmen row in opposite ways, the boat will then go straight. It is more or less the same notion that underlay the medieval trial by ordeal except that, instead of resting on a faith in God, it rests on a faith in the mystical powers of jurors (and others) to find truth most reliably when they are maximally misled.

Like many counterintuitive notions, this one has a certain mystical appeal. As testimony to that appeal, volumes are written on nice ethical questions such as how close a lawyer can come to presenting a falsehood without actually lying. Some say that fraudulently premising an entire case on a client's false plea of non-guilt does not count as a lie, but allowing the client to testify to the same effect does. ${ }^{28}$ Others would allow the client to testify falsely, but draw the line at letting the lawyer elicit the testimony by questions on the stand. ${ }^{29}$ Some see almost no need for limits at all, as long as the lawyer does not actually "know" the facts to be false, but only "reasonably be-

28. This was apparently the view of Chief Justice Burger, the author of the majority opinion (and a great deal of dictum) in Nix v. Whiteside, 475 U.S. 157 (1986) (denying that an accused has a constitutional right to counsel's help in presenting false testimony). See discussion of the Chief Justice's earlier statement of his views in FreEdman, supra note 4, at 44-45.

29. See People v. Guzman, 755 P.2d 917, 933 (Cal. 1988); D.C. CT. R. AnN., Rules of Professional Conduct § 3.3(b) (1996). 
lieves" that they are. ${ }^{30}$ Less cunning folk are apt to have difficulty making these distinctions, and there is good reason. As far as principled honesty is concerned, they do not exist.

The deep faith that lawyers have in their particular version of the adversary system leads them to seriously underrate the significant distorting effects of such adventitious factors as advocacy acumen, negotiating posture, the chance distribution of evidence among the parties, and other collateral influences that almost invariably come into play. Lawyers do notice such factors, to be sure, and they especially tend to notice them when their own clients suffer their effects. Rare, however, is the lawyer who feels guilt or shame by "pulling one off," i.e., successfully pursuing a claim that he or she afterwards learned was lacking in merit, or successfully asserting an insincere defense. Such occurrences are far more likely to be occasions for professional pride, a job well done. Certainly the lawyer has no current ethics-code basis for feeling chagrin in such cases. As long as the other side had its fair shot, and nobody told an outright lie, well, that's the system we have.

It is hard to see how conscientious people can truly feel comfortable supporting a system in which "pulling one off" is not in itself a cause for shame. Yet, that too is part of the system we have. The problem of eliminating adventitious distortions from legal processes is unlikely ever to be solved entirely, but it takes a huge leap of faith to conclude that a good partial solution lies in letting lawyers play games with the truth.

One might also refer here to the highly uneven distribution of lawyer services. To go back to medieval analogies, a system of trial by combat imposes decided disadvantages on those who cannot afford a sword. Yet, today's adversarial lawyers feel no ethical compunction about unleashing their own substantial forces to devastate the stories of non-lawyer "adversaries"-including under-represented criminal defendants. The problem of access to justice is a topic for another place, but it cannot be overlooked that the present drastic shortfall in legal services to the poor is greatly exacerbated by the fact that our system is,

30. Compare Model Rules Rule 3.3(a)(4) (1983) (prohibition on offering evidence known to be false) with Rule 3.3(c) (1983) (permitting evidence that lawyer reasonably believes is false). 
from bottom to top, an adversary system of a particularly combative sort.

Finally, one must not overlook the systemic pressure that results from the fact that the existing limits on allowable fabrication present occupational challenges that can be profoundly engaging to members of the profession. It can be highly interesting work to weave stories that are false out of statements that are true. It is not unreasonable to suspect, indeed, that the real reason so many lawyers are attracted to our present combative version of the adversary system is that they simply love the contest. With this in mind it is easier to understand why the ABA House of Delegates might want to reject ${ }^{31}$ a proposed duty to disclose detrimental information, even to prevent client fraud, while hanging tenaciously to the duty to refrain from outright lies. The lawyer's duty not to make false statements plays somewhat the role in advocacy that the net plays in tennis-it elevates the challenge and enhances the sport. But no one would want a rule that volleys must be placed, if possible, where the opponent can nail them.

\section{VII.}

It is not surprising that lawyers raise objections to standards of honesty like those proposed for NAHL. What is surprising is the vehemence and even indignation with which the objections are expressed. Below are a number of the objections that I have heard, and some thoughts about them.

1. Lawyers already are required to be honest. The idea here is that, it is enough just to avoid telling affirmative lies or half-truths. In effect, this objection asserts that the word "honest" can properly apply even without a full and complete disclosure of all material information, especially to adversaries.

It is not hard to see why such an objection would arise. To say that non-disclosures are not "honest" understandably challenges the self-concept of many legal practitioners who are moved by high motivations to resort to the concealments and dissimulations that are common in traditional adversary practice. It is, however, a deception of self to think that something

31. See supra text accompanying notes 14-16. 
is honest just because it happens to serve a worthy goal. As suggested below, there may be rare circumstances-such as when life and death are in the balance-where dishonesty is justified, but dishonesty is never honest.

2. Clients do not really want honest lawyers. Perhaps this is sometimes true. Even when it is true, however, it is not a very strong argument against strict lawyer integrity. What is good for people who need a lawyer is not necessarily good for the nation as a whole.

Still, considerations of this sort are not easily dismissed. People should be generally free to engage whatever services they will, so long as they do not breach contemporary standards of legality, decency or morality, and the ABA's present rules on lawyer honesty apparently do not do that. At most, however, these kinds of considerations only suggest the advisability of implementing lawyer honesty on an initially voluntary basis, and that is exactly what the National Association of Honest Lawyers would do. If it turns out that clients really do not want to retain honest lawyers, the members of NAHL would soon be forced to drop their membership and the experiment in honesty would be at an end.

3. Clients are entitled to a zealous defense. While clients have a right to a zealous defense, it does not follow that anyone has a right to a dishonest defense. ${ }^{32}$ Nor does it follow that anyone has a right to a defense based on deliberate obfuscation. Suppose, for example, an eyewitness has correctly identified a defendant as being near the scene of a crime, but the witness was near-sighted and not wearing glasses. Some would insist that zealous representation requires defense counsel to bring out these facts about the witness even if the underlying implied "fact," mistaken identity, was thought to be probably false. ${ }^{33}$ Such a rebuttal challenge is, however, effectively a lie. An honest defender would not, therefore, offer such a rebuttal with the specific aim of creating a false impression in the jurors'

32. Cf. Nix v. Whiteside, 475 U.S. 157 (1986). But cf. dissenting opinion in United States v. Wade, 388 U.S. 218, 256-58 (1967) (White, J., dissenting); Lowery v. Cardwell, 575 F.2d 727, 730 (9th Cir. 1978).

33. Freedman, supra note 4, at 30-31, 48; Subin, supra note 12 , at $150 \mathrm{n} .113$; and Mitchell, supra note 8, at 352-54. 
minds. The rebuttal would be honest only if the defender genuinely believed, with reason, that the identification was doubtful.

One can, however, be zealous and still be honest. The only thing that is excluded is the zealous pursuit of dishonest aims or means. This will, to be sure, usually prevent the zealous pursuit of an undeserved acquittal (except as discussed in the next section). The absence of an honest exoneration defense does not, however, mean that there is nothing for the defense to "zealously" do. There are still matters such as the gravity of the charge, factors in mitigation, and choice of disposition-the basic stuff of plea bargaining. If the accused cannot, by demeanor or otherwise, make even a somewhat convincing or plausible case of innocence to a sympathetic audience like his own lawyer, it is pretty unlikely that the defense should be focusing on anything but these matters anyway.

In any case, for all the insistence that honest lawyering would be bad for criminal defendants, the claim seems to be basically emotional and impressionistic. There does not appear to be any empirical evidence that defendants on the whole would be worse off if criminal defense lawyers were scrupulously honest. This may be especially so if the emergence of an unconditionally honest defense bar had the collateral effect of forcing prosecutors to be scrupulously honest, too. Even if only the defenders were honest, however, it is still not clear that defendants on the whole would be worse off than they are now. The innocent ones would most likely be even better off if represented by a lawyer whose reputation for probity were beyond reproach. ${ }^{34}$

In evaluating the net effects of honest lawyering on criminal defendants, however, it is important to take into view the likely profound impact on the criminal prosecution system of a voluntary movement of certified honest lawyers, a movement

34. For example, in his earlier days as a California county prosecutor, Chief Justice Earl Warren and the local public defender developed a relationship of trust that apparently worked to the considerable advantage of the latter's innocent clients. According to the public defender:

"[Warren] said that anytime I was convinced he was prosecuting an innocent man, I should tell him so. He would let me look at his files and, if that didn't change my mind, Warren would not prosecute. He trusted me to be as honest with him as he was with me."

Leo Kratcher, Earl Warren: A Political Biography 57 (1967). 
that prosecuting attorneys may also choose to join. Indeed, it seems probable that prosecuting attorneys would be under enormous pressures to become members of NAHL once any number of defense attorneys did so. If prosecutors refused to assume the same monitored ethical duty of full disclosure as assumed by defenders, citizens and potential jurors could easily be made aware of that fact by informational advertising done by NAHL itself.

A better assumption is, however, that prosecutors would quickly move to align themselves with NAHL principles (to which they nominally are committed anyway). ${ }^{35}$ The entire complexion of criminal proceedings could then be very different. The prosecution would be externally monitored not only with respect to its duties of honesty and full disclosure, but also with respect to its duty to use due diligence in verifying the evidence, including police testimony, that it presents. In such a situation, any downside there might be to having a scrupulously honest defender could be more than offset by the advantage of having a scrupulously honest prosecutor, one who is limited to meticulously vetted police evidence. ${ }^{36}$

35. See, e.g., the non-binding but influential American Bar Association Standards Relating to the Administration of Criminal Justice § 3-3.11 (Disclosure of Evidence by Prosecutor) (1992), reprinted in STEPHEN GILLERS AND RoY D. Simon, Regulation of Lawyers: Statutes and Standards 541 (1999). "The duty of the prosecutor is to seek justice, not merely to convict." AMERICAN BAR Association Standards Relating to the Administration of Criminal Justice § 3-1.2(c), reprinted in Selected Statutes, Rules and Standards on the Legal Profession 535 (1994). The matter is also now covered more obliquely in the Model Rules. Model Rules Rule 3.8(a) (1983) (requiring a prosecutor to "refrain from prosecuting a charge that the prosecutor knows is not supported by probable cause").

36. Although some of the sharpest questions about the profession's standards are targeted at criminal defense lawyers, the defense side of the criminal law bar is hardly the only one needing some profound ethical self-examination. Recent studies on the use by prosecutors of questionable police testimony and other strategies to obtain convictions raise issues that are also serious. See, e.g., Stanley Z. Fisher, "Just the Facts, Ma'am: Lying and the Omission of Exculpatory Evidence in Police Reports, 28 New Eng. L. REv. 1 (1993); and Myron W. Orfield, Jr., Deterrence, Perjury, and the Heater Factor: An Exclusionary Rule in the Chicago Criminal Courts, 63 U. CoLo. L. REv. 75 (1992) (on the confessed willful blindness of prosecutors in presenting perjured police testimony). The variety of ways in which prosecutors can and sometimes do abuse their power, and some reasons for the persistence of such abuse, are outlined in Bennett L. Gershman, Abuse of Power in the Prosecutor's Office, reprinted in CRIMINAL Justice: OpPosing ViewPoints 156 
Finally it should be remembered that when criminal defense lawyers are believed to be none too scrupulous in their manner of defense, it does none of their clients a service. A person who makes himself generally not believable is one who will

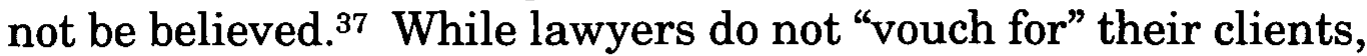
they should at least be willing to vouch for themselves. The lawyer who presents the client's position as a zealous actor, with a forthrightly feigned commitment to a belief, invites a skeptical reception. ${ }^{38}$ What can it mean if the lawyer says in effect (as lawyers do now): "I do not necessarily believe all this that I'm telling you and, as far as I know, neither does my client." An advocate, however, is not just a zealous actor. An advocate is a person who sincerely presents a position that at least somebody believes.

(Michael D. Biskup, ed., 1993). See generally Bennett L. Gershman, Prosecutorial Misconduct (1984).

Professor Pizzi appears to believe that the special ethical constraints mean that prosecutors do not exhibit "adversarial excess" as much as defense attorneys. William T. Pizzi, Trials Without Truth 137-38 (1999). It should be remembered, however, that these constraints are largely self-enforced and, even with them, there is still reason to believe that erroneous convictions occur in a worrisome proportion of cases. See, e.g., Alan Berlow, The Wrong Man, Atlantic Monthly, November 1999, at 66,68 (describing the relatively high rate of erroneous convictions in death-sentence cases: one conviction overturned for every seven executions), citing a 1996 U.S. Justice Department Report, reprinted as Commentary of Peter Neufeld and Barry C. Scheck, in Edward Conners et al., Convicted by Juries, Exonerated by Science: Case Studies in the Use of DNA Evidence to Establish Innocence After Trial, 37 JuRIMETRICs J. 341, Spring 1997 (estimating, based on DNA exonerations of persons convicted of rape, that as many as $25 \%$ of convictions may be erroneous). If we accept the assumption that unvarnished admissible evidence is a reliable basis for determining truth, then these erroneous convictions arouse the suspicion, at least, that some prosecutors may be trying to enhance their chances of victory by toning up the proof, concealing exculpatory matter and otherwise skirting the rules. Such prosecutorial zeal to convict may be due in part, Professor Pizzi explains, to a tendency of prosecutors to identify with and become vested in their cases. See Pizzi, at 118-19.

37. One commentator has suggested that when corporate lawyers behave in untrustworthy ways for one client they breach their fiduciary duties to all their clients. The duties of loyalty and zealous representation include, in other words, an obligation to avoid conduct that subverts the lawyer's own credibility and, hence, effectiveness. Peter Kostant, Paradigm Regained: How Competition From Accounting Firms May Help Corporate Attorneys to Recapture the Ethical High Ground, 20 PACE L. Rev. 43, 65 (1999).

38. See Robert C. Post, On the Popular Image of the Lawyer: Reflections in a Dark Glass, 75 CAL. L. REv. 379 (1987) (making the lawyer-actor analogy). 
4. Getting at the truth is not really the purpose of the system anyway. This objection is made most especially with reference to the criminal process which, as one commentator has said, 'is not a 'truth system' in any sense in which one could reasonably understand that term." 39 It is, under this view, simply an error to think that the main purpose of the justice system is to apply the substance of the law to the things people actually do. As apparent support for this position, one can point to any number of substantive and procedural rules whose use can lead to the dismissal or exoneration of defendants who have, in truth, committed proscribed acts. These include (potentially) most of the rules of evidence, many procedural conventions and regulations, and various affirmative defenses.

Nevertheless, it is likely that most people would be repelled to hear that the American system of justice is not a "truth system" in any reasonable sense. For most, one might guess, the whole moral validity of law would be nonexistent if legal outcomes were actually supposed to be decided by factors other than truth. The core idea of justice presupposes that the law applies rules that are just to the events that actually occur. If the concept of "right" in our nation really just comes down to who wins regulated competitions to reinvent the past, it is because non-honest lawyers have hijacked the legal system.

The real fallacy in this is, however, elsewhere. The real fallacy is to jump to the conclusion that the legal system is not a truth system merely because some of its rules allow some defendants to be discharged despite what they have done. Rules of this sort do not necessarily get in the way of truth at all. They only do so when they are invoked in order to avoid the law's intended substantive result, as applied to the actual facts. On analysis, it appears that the rules permitting dismissal or exoneration of defendants who "did it" can be divided into three very different categories.

39. Mitchell, supra note 8 , at 341. Professor Pizzi agrees, stating that the United States justice system "places too low a priority on truth in the system." PizzI, supra note 36, at 71-72. See generally PIzzI, supra note 36, at 21 (stating that the United States justice system is not a system that places a high priority on truth). Accord Freedman, supra note 4, at 3-4 (stating that the "adversary process has its foundations in respect for human dignity, even at the expense of the search for truth ... [t]ruth is a basic value . . but may on occasion be subordinated to even higher values"). 
First, there are the rules whose very purpose is to override the policy of making offenders incur punishment for criminally proscribed acts-various immunities, statutes of limitations, and substantive defenses, such as necessity or the protection of persons. Because these rules are frankly intended to exonerate even if the defendant actually did a forbidden act, the lawyer who honestly invokes these rules in defense is in no way derogating from the truth about the defendant's conduct. Rather, by invoking these rules the lawyer is asserting that the truth of what the defendant did is, in the final analysis, legally beside the point.

Crucially different, however, are the law's many rules whose purpose is to increase the reliability of truth finding processes. These include most of the laws of evidence and rules governing trial procedures, such as the right of cross-examination. Unfortunately, these truth-reliability rules are something of a double-edged sword. They can often be asserted to obfuscate or hide the truth. That is not, however, their purpose. Accordingly, when a lawyer asserts or uses a truth-reliability rule as a deliberate means to disguise the truth, hoping for an outcome that is in spite of the truth, it is a pure and simple perversion of its purpose.

Finally, there are rules that are neither intended to exonerate people who have committed statutorily proscribed acts nor to enhance the reliability of the search for truth. Instead, they are aimed at advancing certain policies even at the expense of truth. Various testimonial "privileges" fall into this category, as well as (in my view) the so-called "exclusionary rule," which allows exclusion of evidence that has been illegally obtained. ${ }^{40}$ Anyone committed to truth as the basis for action may face difficult dilemmas when it is the very policy of the law to conceal secrets or information at the expense of substantively "right" results. While I would not propose that the honest lawyer attempt to defeat such overriding policies in the name of truth, I do think it incumbent on the honest lawyer to do everything possible to bring forth the truth without violating such policies. This means, at very least, including waivers of confidentiality and the attorney-client privilege in retainer agreements so that

40. See Mapp v. Ohio, 367 U.S. 643 (1961). 
the lawyer does not, at any rate, become a routine source of such dilemmas.

5. When criminal defenders reveal confidences, the client with counsel is deprived of the right to make the government prove its case. The right of an accused defendant to put the government to its proof is a fundamental one.41 Also, undeniably, the rule that the government must prove its case has its fullest meaning only if defendants are free, with the help of counsel, to challenge and probe out the weaknesses in the evidence that the government presents. It is obviously not possible to allow only innocent defendants to test out the government's evidence. So, the argument goes, the only option is to confer upon all defendants, guilty and innocent alike, the unqualified right to challenge and probe the government's case. This is so even though in the case of the guilty the ultimate "fact" implied by such attacks is counterfactual-namely, that the defendant did not commit the crime. ${ }^{42}$

There is, however, nothing inherent in a system of honest advocacy that would ipso facto deprive criminal defendants of the right to put the government to its proof. The defendant would still be protected by the rules against forced self-incrimination and the principle that the government has the burden of proof beyond a reasonable doubt. The government would still have to be ready to make its case on its own, without resort to the (unwilling) defendant. The only difference under a system of honest lawyering is that the defendant who wants to contest the government's case would have to do so truthfully. That is, the honest lawyer would not force the government to prove its case unless there are points of genuine controversy, so the government has something it needs to prove. The defendant would not be entitled to the honest lawyer's help merely to pretend controversy in the hope that some undeserved advantage might emerge from the contest itself. That is the difference.

It may be objected that the practical effect of prohibiting fabricated controversies over issues of fact is nevertheless to lessen the government's burden against the accused. This may

41. See In re Winship, 397 U.S. 358, 364 (1970) (holding that the prosecution has the burden of proving its case beyond a reasonable doubt).

42. See Subin, supra note 12 , at 145-46. 
be true, but in only one respect: Under a system of honest lawyering the government's case would not have to be strong enough to withstand a fabricated or misleading defense. There is, however, no known constitutional requirement that the government's case must be able to stand up to a fabricated or misleading defense. Nor is there a compelling policy reason for such a requirement.

From the standpoint of liberty, perhaps the most crucial function of the government's constitutional burden of proof is that it disciplines prosecutors to screen out those accusations that are backed only by questionable evidence. In a system of honest advocacy, this all-important function would probably be little affected. For one thing, guilty defendants would still be able to pretend innocence as a strategy, and the government would still have to be ready for them. The government side could not, that is, ever ignore the possibility that a guilty defendant would deny guilt, even to his own lawyer, until the very end. More importantly, the government could never ignore the possibility, especially when its evidence is questionable, that the accused is actually innocent and therefore likely to fight the charges and evidence in every aspect. These innocents are presumably the defendants we most have in mind to protect with our present burden-of-proof screens against unwarranted prosecutions. Because these defendants would have no more reason to give in under a system of honest lawyering than they would today, prosecutors' incentives to avoid pursuing them would presumably be as great as ever.

Lawyers sometimes talk of the government's burden to prove its case almost as though it creates a substantive right to commit crimes with impunity as long as the government cannot overcome this key procedural hurdle. ${ }^{43}$ This is hardly likely to be the case, and the prospect of having this "right" taken away is hardly a sound argument against honest lawyering. A stronger reason for not letting the government resort to the defendant in making its case (and not letting it force defendants to prove innocence) is to forestall the use of investigative duress in obtaining "confessions." Since today's prosecutors routinely use what amounts to duress in obtaining confessions anyway (a pro-

43. See Mitchell, supra note 8 , at 342 . 
cess known as "plea bargaining"), the protection of the burdenof-proof rule for this purpose may be, as a practical matter, far more illusory than is usually admitted. Nevertheless, with the plea bargaining process being the predominate mode of criminal case disposition, the impact of defender honesty on plea negotiations is a highly central question.

In thinking about this question, one of the most obvious things to consider is the key strategic role played by claims of innocence as a bargaining chip in the plea negotiation process. Just saying "I didn't do it" can mean the difference between liberty and jail. The fact that it may sometimes be a false bargaining chip does not mean it cannot be a powerful one.

It seems a plausible guess that having honest defense lawyers would, if anything, make innocent defendants by and large better off in the negotiation process. The lawyer who is known to use the "he didn't do it" defense only when honestly convinced of its truth is far more likely to be taken seriously than one who uses the defense indiscriminately. ${ }^{44}$ The situation for guilty defendants is, however, something else again.

Having honest defense lawyers would clearly be a drawback for at least one class of guilty defendants: those who want to pretend innocence (fabricate controversy) in the hope of getting an unmerited reduction of charge, dismissal or decision not to prosecute. In order to pretend innocence, such defendants would also have to lie to their own lawyers, and clients who lie to their own lawyers take substantial risks. By lying, they deprive their lawyers of the truthful information the lawyer may need to get the best deal and minimize penal consequences. Even if this is so, however, it is still not a sound policy argument against an ethic of honest lawyering. In a world of honest men and women, the scoundrel may be at a disadvantage, but that does not mean honest people should become scoundrels in order to compensate. Honest lawyers should not become dishonest just so the guilty can have the help of counsel in asserting a false defense.

Far more troublesome is the possibility of an innocent defendant who, by a horrible confluence of coincidence, appears to be utterly implicated by "true" though illusive evidence. The

44. See supra note 34. 
"falsely implicated innocent" is a person poignantly invoked in debates over routinely claiming innocence for clients who are most likely guilty. The idea is that, unless criminal defense lawyers are free to argue the non-guilt of all defendants, there may be no defense, and no hope, for falsely implicated defendants. The right to propound an implicit lie is justified, in other words, as a necessary escape hatch for those unfortunates who, against all the evidence, actually are innocent.

A compassionate person might want to do almost anything to rescue a falsely implicated innocent from his or her predicament. It does not follow, however, that doing just anything is justified. Certainly an armed raid on the police station would not be justified. Although lies are less dramatic, it is not clear that a rescue by implicit lies could be justified either. ${ }^{45}$ And it is not just a matter of implicit lies being "bad." The problem is that, when the law allows escape hatches based on fiddling with the facts, the undeserving can slip out just as easily as the deserving. While it may be better that "a hundred guilty go free than one innocent be jailed," it is not that simple.

Escape hatches based on dissembling the facts cut at the heart of the law's integrity as an arbiter of actual conduct. When the system's integrity is debased with fact-finding escape hatches, it adjusts in other ways as well. Lawyers who routinely claim non-guilt for the innocent and guilty alike, end up being routinely unbelievable no matter who their client is. Their entreaties for both the good and bad alike come to be taken with the same small grain of salt. A myriad of other provisions are built into the process so false deniers will not get away, and then truthful deniers get caught in the snares. An accusation or arrest becomes an ever stronger indication of guilt, and convictions become ever more unchallengeable. As false defenses undermine the credibility of even true defenses, the system becomes less and less reliable as a screen based on truth. Even more innocents may sit in prison so a few can go free.

In sum, the requirement that the government must prove its case before penalizing an accused is a necessary but not a sufficient condition for constitutional liberty. By pressing that

45. See supra section VI. 
condition to an extreme, it may operate at the expense of other essential conditions. One of these other conditions is that people's actions must be judged, for better or worse, by applying the substance of the law to the things they actually do. When defendants are deemed "entitled" to fabricate controversy to force the government to prove its case, some of them may go free due to accidents of the contest. To the extent that this occurs, however, it erodes the system's basic integrity as an arbiter of actual conduct. This may create a climate for other "compensating" adjustments that aggravate even further the divergence between "legal facts" and the actual events to which the laws are supposed to apply. From the standpoint of both liberty and truth, these compensating adjustments can be far worse than convicting a guilty person based on admissions made to counsel.

A system of honest lawyering would not eliminate the requirement that the government must prove its case. The only inroad it would make is to try to limit that requirement to situations of genuine controversy-where the defendant's honest view of what happened really does differ in essential respects from the government's. The system's basic integrity as an arbiter of actual conduct would be reinforced. ${ }^{46}$

6. Some clients, especially criminal defendants, have too much at stake for their lawyers to be honest at their possible expense. Incarceration and loss of liberty or even life are more drastic by orders of magnitude than the stakes in most civil proceedings or transactional negotiations. No person, the objection might go, is morally obliged to "play fair" or cooperate

46. One particular fifth amendment concern should be mentioned in this context. It is the possibility that honest lawyer standards might eventually be taken over legislatively or judicially by government organs and enforced by the power of the government itself. For fifth amendment reasons this would be highly objectionable because it would make defense lawyers answerable directly to the government for their due diligence in assuring their clients' full disclosure. With defense counsel thus answerable to the very government that is the litigation adversary, it is not unrealistic to anticipate a potential for abuse. Such abuse, by turning the attorney's due diligence into a government investigation, could profoundly undermine the purposes served by the privilege against forced self-incrimination and the defendant's right to make the government prove its case. In order to avoid such potential for abuse, enforcement of the lawyer's duties should be exclusively in the hands of private agencies who are not answerable to the prosecutorial entity, viz. the government. 
with those whose goal is to intentionally inflict misery or suffering on him or her.

I have some sympathy with this objection. It suggests in effect that harsh treatment and brutality elsewhere in the system dissolve the moral imperatives that might otherwise apply at the entry stage. The focal point of the problem can be highlighted by taking a nondebatable case. If I lived in Europe in the early 40's, and the secret police came asking the whereabouts of a neighbor, I would have had no moral qualms about telling a lie to save a life. Though a lawyer has a responsibility of honest and meticulous disclosure, the responsibilities may be very different when the primary object of the enterprise is profoundly immoral.

The closest contemporary American analogy, though more "disputable," is raised by the death penalty. There are many who believe that the killing of another human being is profoundly immoral. The political majority, however, disagree, seeing such homicides as an occasionally acceptable means for achieving a social end.

The real question here, it seems to me, is whether a lawyer who believes that killing is immoral should participate in the defense of capital cases at all. Such a lawyer's moral dilemma is not easily solved. It is not solved at all by the mere fact that the defense attorney takes part in order to oppose capital punishment. The fundamental problem of complicity still exists: The defense lawyer in a capital case functions as the velvet glove that ensheathes the iron hand. By supplying the prosecution with an "adversary," the anti-death defender helps give moral cover to what is, in his or her terms, an intrinsically immoral project.47 For a lawyer who honestly holds anti-death penalty views, complicity can be avoided only if participation is merely a ruse to covertly impede the process from the inside. Such a lawyer might then do exactly what he or she would have done in 1940's Europe: tell lies to save lives.

The conclusion I reluctantly reach, however, is that such a lawyer should not participate in the process at all. A person who is not willing conscientiously to observe the lawyer's obliga-

47. The death case defender gives legal cover, too. As one friend has pointed out to me, under present constitutional standards, all it would take to abolish the death penalty is for lawyers to stop defending the cases. 
tions of honesty and disclosure should not choose to practice in a court of law, at least not in cases brought to achieve ends, such as execution, that he or she considers morally repugnant. In fact, acting as defense attorney may actually be a disservice to the defendant anyway. Any arguments made as to why an outcome (say, the death penalty) should not apply in the particular case may not be taken very seriously if everyone knows that the speaker would oppose such an outcome in every case.

For the lawyer who feels that, prison conditions and sentencing being what they are, any accused has too much at stake to "play fair," the dilemma is essentially similar. As explained earlier, the rationales for honest practice are not metaphysical but systemic - to promote justice according to law and the democratic form of government. If the regime is believed to be lacking on either of these scores, systematically or in the particular instance, then so is the rationale for honest behavior within it. Any other scruples one might have about deceit are subject to the lesser evil doctrine: the lawyer may deceive (an evil) if necessary in order to prevent a greater evil (e.g., the unjust or inhumane treatment of another human being). Such a lawyer, if honestly committed to his or her convictions, would not, however, stop with the genteel implicit lies condoned by present ethical rules. This is, needless to say, the most dangerous of ground.

It is also probably pointless ground, as well. If the justice system truly harbors deep injustice, it is hard to see how things are much improved by having random factors in the mix. The element of chance introduced by pretended controversies might yield occasional counterfactual acquittals, but that does nothing at all to address systemic fault. More likely, the fabrication of false defenses mostly just consoles socially committed defenders with the delusion that they are at least doing something to address the injustices they perceive. All they are really doing, however, is subverting their own ability to protect the innocent while fruitlessly playing doorman at the revolving door to jail.

7. Negotiations would cease to have meaning. There would be nothing to negotiate. As one lawyer said to me, skeptical of fully honest lawyering: "What would happen to negotiations? You couldn't disguise your weaknesses. You 
wouldn't be able to hold back for effect. You could never drop a bomb." That is, of course, precisely the goal.

Negotiations would, of course, still be necessary and there would be plenty to negotiate. Honesty does not eliminate all differences, and negotiations will always be needed whenever there is an honest difference of interests or of values or valuations, or even of visions of reality. Even if everybody were entirely honest and candid in negotiations, there would still be many issues for negotiations to resolve. First, there would be the need to make sure whether and in what respects the parties actually do differ, not always an easy-to-answer question. Secondly, there would be the need to define some sort of common denominator as the basis on which the parties could make one another conjointly better off. What would be missing would be the opportunity to gain an extra advantage by surprise, dissimulation, and a myriad of other familiar deceits. At least the assistance of an honest lawyer would not be available in pursuit of such strategies.

Who would ever want to employ an honest lawyer in negotiations? In time, it may be thought that almost everybody would. Everybody, at least, who wished to be taken seriously in their negotiating positions would want an honest lawyer. Indeed, it could easily become the case that astute businesspeople might even refuse to do deals with counterparts who do not employ the services of honest lawyers unless there were a really compelling reason to do so. That is, in time, businesspeople who do not come to the table with an honest lawyer at their side would find themselves at a significant economic disadvantage. It never helps if, compared with your competitors, your negotiating positions are distrusted or your propositions pre-discounted in the eyes of those with whom you deal.

8. Honesty is not practical because it is not enforceable. The perennially strongest argument for doing wrong is that doing the right thing is "impractical." In the end, however, this claim is just another way of saying that "it suits my purposes better not to do what's right," for it is the purposes that are key. No action is either practical or impractical in the abstract, but only in relation to one or another purpose. The real issue is what the purposes are and, perhaps, whether serving them in a particular way tends to disserve some other, weight- 
ier goal. The purposes of being honest are that it is right, and that most people are better off in a world in which trust is generally possible. The need to make allowances for well-founded mistrust is a deadweight social cost. What then are the purposes of a lawyering ethic of manipulation and distortion? Presumably the purpose of such tactics is to level the playing field, so that liars will not have special advantages. As long as other lawyers are evasive and manipulative, the logic goes, all must act accordingly or the contest won't be fair.

It is clear that the ideals of NAHL will never be completely enforceable, just as the present ethical prohibitions on direct lies are not completely enforceable. There will always be those who chisel around the corners and flat-out cheat on the rules, paying lip service to truth while trying to gain advantage by falsehood. People who try to play this game will, until caught, reap undeserved benefits at the expense of those who do not. But the same may be said of pickpockets and thieves. Until they are caught, they sometimes get the better of those who do not steal, yet no one claims that larceny laws are "impractical" or that they should be repealed in order to level the playing field for all. Instead, we each watch out for suspicious behavior in others, try to avoid acting in a suspect way ourselves, and roundly condemn the violators when they are caught. Even though the rules against stealing are not completely effective, it is better to have them than not. It is likewise for rules of fully honest legal practice. The question of whether they are practical turns not on whether they will be perfectly enforceable or unfailingly observed, but only whether it is better to have them than not.

\section{VIII.}

The ideal behind NAHL's standards is not particularly new or radical. ${ }^{48}$ It may seem unprecedented but, then, so at one time were such social advances as democracy, individual free-

48. One of the most ambitious proposals for increasing lawyer honesty was made by Professor Harry I. Subin. See Harry I. Subin, The Criminal Lawyer's "Different Mission": Reflections on the "Right" to Present a False Case, 1 Geo. J. LeGAL ETHICS 125 (1987). Even this proposal was, however, compromised in that it condoned the use of non-disclosure to evade sanctions called for by the substantive law. By continuing to accept the legitimacy of letting the law be misled, it embod- 
dom, and the policy of equality before the law. The ethical stance of lawyers towards truth is similar to that of merchants in the days of caveat emptor. To tell an outright lie is wrong, but to leave an erroneous impression, or even to strive to create one, is considered intrinsic to the task. ${ }^{49}$

A large part of the reason why lawyers are not punctiliously honest is that, for the most part, lawyers do not think that deluding others is ethically wrong or questionable-as long as there is no outright lie. Not only do lawyers see nothing wrong with mere concealment, obscurantism or bending the facts, most would probably agree that to not do these things would itself be an affirmative wrong. To be totally candid to the adversary about the realities of the world as the lawyer and client see them would constitute a stark betrayal of the lawyer's duty to serve the client's interest. Clearly, as long as attitudes like these prevail, genuinely honest lawyers will not.

Perhaps the most important function of NAHL would be to make "respectable" and reinforce an ethic of punctilious honesty in law practice. It would be the role of NAHL to proclaim and attest by its members' conduct the wrongness of concealment and deceit and the rightness of a fully honest approach to legal practice. It would provide enforcement mechanisms for deviations at the fringes, but its primary efficacy would have to be in the power of its message as conveyed by its members to their peers. When concealment, obfuscation and bending the facts are no longer considered acceptable behavior, virtually every lawyer should at least be dampened in his or her enthusiasm for such practices. Some, to be sure, will never be dissuaded, and neither sanctions nor principles nor the fear of causing outrage will turn them from their willingness to cheat on the truth. Nevertheless, it is almost surely the case that the profession will be vastly more candid, forthcoming and honest under a set of ethics principles that extol such values, than it is under the present rules which, in their essence, treat excessive honesty as a cause for disgrace.

ied an inconsistency and left a wide opening for critiques. See Mitchell, supra note 8.

49. I am indebted for this analogy to Richard S. Plattner, Esq., Plattner Verderame, P.C., Phoenix, Az. See In re: Ethical Rules 3.0, 3.3(a)(2), 4.1 and 1.6, Petition To Modify Ethical Rules 3.0, 3.3(a)(2), 4.1 and 1.6. (Ariz. Sup. Ct. R93-0048). 